\title{
Effects of soil compaction on growth and survival of tree saplings:
}

\author{
a meta-analysis
}

\author{
E. Ampoorter ${ }^{\mathrm{a}}$, P. De Frenne ${ }^{\mathrm{a}}, \mathrm{M}$. Hermy $^{\mathrm{b}}, \mathrm{K}$. Verheyen $^{\mathrm{a}}$ \\ ${ }^{a}$ Laboratory of Forestry, Department Forest and Water Management, Ghent University, Geraardsbergse Steenweg \\ 267, B-9090 Gontrode, Belgium \\ ${ }^{b}$ Division Forest, Nature and Landscape Research, Department of Earth and Environmental Sciences, K.U.Leuven, \\ Celestijnenlaan 200E - bus 2411, 3001 Heverlee, Belgium
}

\begin{abstract}
Soil compaction due to mechanized harvesting operations in forests can have profound effects on forest soils and, hence, can have a detrimental effect on subsequent forest regeneration. We performed a meta-analysis to quantify the effect of soil compaction on height growth, diameter growth, and survival of tree saplings. These effects were predominantly insignificant, varied strongly and were thus not unambiguously negative. Only on silty soils, growth and survival were significantly reduced by soil compaction, which contrasted with sandy and loamy soils, where the effect of soil compaction was negligible or even slightly positive. A weighted analysis revealed an overall decrease of height growth on the compacted area, but this result should be interpreted with caution due to the limited number of observations. Although results did not show an overall negative effect of soil compaction, harvesting activities should focus on minimizing soil compaction degree and extent to prevent a decrease of soil productivity. From a methodological point of view we suggest providing more basic statistics in the articles and to include more shadetolerant tree species in future experimental designs. These species are currently underrepresented.
\end{abstract}

Keywords: forest, mechanized operations, compaction degree, diameter, height, response ratio, texture

\footnotetext{
* Corresponding author. Tel.: ++32(0)92649038; fax: ++32(0)92649092.

E-mail address: evy.ampoorter@ugent.be.
} 


\section{Introduction}

The use of heavy machinery to perform forestry activities such as logging has increased worldwide during the last decades. However, these machines may seriously influence the soil ecosystem as they induce rutting, churning of the upper soil layers, and soil compaction. The latter implies a decrease of soil pore continuity (Benthaus \& Matthies, 1993), compression of soil pores, and an increasing soil bulk density (Cullen, Montagne \& Ferguson, 1991). Aust, Burger, Carter, Preston \& Patterson (1998) stated an increased penetration resistance after machine traffic, a measure for the resistance that a soil exerts against root growth. Moreover, Ballard (2000) reported changes in soil water retention and hydraulic conductivity. Several studies indicated an increase of soil $\mathrm{CO}_{2}$ concentration and decrease of $\mathrm{O}_{2}$ concentration due to an unfavourable influence on soil aeration (e.g., Startsev \& McNabb, 2009). Tan \& Chang (2007) showed that soil compaction also had a negative effect on net nitrification rates, although Blumfield, Xu \& Chen (2005) did not notice a significant effect on nitrogen mineralisation or nitrification.

Heavy soil damage may impose a serious threat to soil ecosystem functioning. Higher penetration resistance reduces elongation and penetration of roots, and thus lowers the uptake of water and nutrients (Kozlowski, 1999). A higher seedling mortality and reduced tree growth was observed by Gebauer \& Martinková (2005). The level of these effects depends on soil type and examined tree species (Gomez, Powers, Singer \& Horwath, 2002; Heninger, Scott, Dobkowski, Miller, Anderson et al., 2002). Cheatle (1991) found that tree survival and basal areas of Terminalia brasii were much lower on compacted soils. Detrimental effects on growth of Pinus contorta on a sandy clay loam soil were observed by Bulmer \& Simpson (2005). Rhoades, Brosi, Dattilo \& Vincelli (2003) showed that the mortality of Castanea dentata seedlings due to the incidence of Phytophthora root rot was largest in wet, compacted soils. However, Sanchez, Scott \& Ludovici (2006) found that severe soil compaction had an insignificant effect on mean stand volume of Pinus taeda. Nabe-Nielsen, Severiche, Fredericksen \& Nabe-Nielsen (2007) showed that the regeneration of Ficus boliviana and Terminalia oblonga even increased on compacted soils, and Alameda \& Villar (2009) found a higher total biomass at higher compaction degrees possibly due to a greater root-soil contact. According to Fleming, Powers, Foster, Kranabetter, Scott et al. (2006), conifer survival and growth benefited from soil compaction, regardless of climate and species. Apart from the influence on tree growth and survival, soil compaction may also influence the vitality and diversity of understory plants (e.g., Zenner \& Berger, 2008), soil macrofauna such as earthworms (e.g., Jordan, Hubbard, Ponder \& Berry, 1999), and microbes (e.g., Kara \& Bolat, 2007).

Every load on a forest soil changes soil structure to a certain extent. However, not every degree of soil damage is detrimental. Arshad, Lowery \& Grossman (1996) stated that bulk densities are growth-limiting when values exceed $1.47 \mathrm{~g} / \mathrm{cm}^{3}$ on clay, $1.75 \mathrm{~g} / \mathrm{cm}^{3}$ on silt and $1.80 \mathrm{~g} / \mathrm{cm}^{3}$ on loam and sand. USDA Forest Service suggested that a bulk density increase of more than $15 \%$ is detrimental for the soil ecosystem (Powers, Tiarks \& Boyle, 1998). Whalley, Dumitru \& Dexter (1995) found that plant root growth slowed down at a penetration resistance of $2 \mathrm{MPa}$ and stopped when resistance values exceeded $3 \mathrm{MPa}$. Seedling root growth is also reduced when oxygen concentration drops beneath the 6 to $10 \%$ range (Grant, 1993). However, some studies on sandy soils indicated potential positive biotic effects after machine traffic (e.g., Agrawal, 1991). Compaction decreases sizes and continuity of pores that are normally too wide to hold water against gravitational forces. Therefore, water availability increases and this may influence root and seedling 
growth positively. Moreover, several studies indicated that roots may still grow in compacted soils through soil cracks and channels of dead roots (Greacen \& Sands, 1980).

Several studies have examined the effect of soil compaction on tree growth and survival. However, as shown above, results are equivocal: some studies point out that soil compaction is detrimental to the soil ecosystem and the resulting plant vitality while others report no significant or rather positive effects. For the most part, studies examined one compaction degree, one species, taxonomic group or one soil type. To date, no general conclusions can be drawn. We performed a meta-analysis to unravel the effect of soil compaction on tree sapling growth and survival in a more general way across an array of climates, compaction degrees, soil types and tree species. We specifically addressed (a) whether machine traffic had a negative influence on sapling growth and survival on average, and (b) which experimental factors explained the variation in growth and survival responses to compaction?

\section{Materials and methods}

\section{Data collection: search strategy and study inclusion criteria}

The bibliographic database ISI Web of Science (http://apps.isiknowledge.com) was searched to find relevant studies on the overall biotic effects of soil compaction, published between 1955 and 2009. The Boolean search expression was compact* AND forest* AND harvest* (* = wildcard). This procedure yielded 207 articles, of which 69 treated the biotic effects of soil compaction. The reference lists of these 69 articles as well as articles that cited these 69 articles were also examined, resulting in 30 and 10 additional articles on biotic effects, respectively. Finally, Google (www.google.com) was used for additional searching but only one new article was found. Of these 110 articles, 65 examined tree growth and survival, 30 studied the herb layer, and 25 looked at the effects on soil biota (microbiota, earthworms, etc). In this meta-analysis we decided to focus on the effects on tree growth and survival. Namely, a lot of articles concerning herb layer and soil biota lacked essential information, or examined species or diversity indexes were too different to be analysed together. Next, duplicate studies, studies where no clear distinction was made between compacted and uncompacted soil and studies where a combination of soil compaction and litter layer removal was examined, were deleted. Laboratory or pot experiments were also excluded, as in these cases the soil was artificially compacted, root growth was restricted by the pot boundaries, and the soil processes were probably not comparable to the in situ situation. All remaining articles concerned the effects of soil compaction on planted seedlings, resprouts, or natural regeneration, (hereafter called saplings). The effect of soil compaction on established, adult trees could thus not be examined. Height growth, diameter growth, and survival of the saplings were selected as response variables as most articles quantified at least one of these variables. This resulted in 22 studies retained in the final dataset. Six were located in Canada, 11 in the USA, two in South America, two in Oceania, and one in Africa. Detailed information on the selected studies is summarized in Appendix A. Local climates were classified according to the Köppen-Geiger classification (Kottek, Grieser, Beck, Rudolf \& Rubel, 2006). Type of compaction treatment refers to the way that soils were compacted (field trial, Long-Term Soil Productivity Study, recent harvest or old wheel tracks). In several studies compaction was experimentally applied with heavy machinery (skidder, loader, bulldozer, etc), aiming to simulate current traffic intensities or compaction degrees (field trial). Other experimental studies were part of the Long-Term Soil 
Productivity (LTSP) Study, where nine combinations of organic matter removal and soil compaction were applied (Powers, 2006). In the LTSP Study compaction treatments were also intended to simulate prevailing compaction degrees and were often applied using a compactor head on an excavator or a heavy roller pulled by a tractor. In the remaining studies soils were compacted by virtue of recent (recent harvest) or former (old wheel tracks) harvests.

\section{Data preparation and analysis}

\section{Predictor variables}

Because some studies examined the effect of several traffic or disturbance intensities, harvesting regimes, locations or tree species, data for each combination was included as an individual substudy. This yielded a total of 41 substudies for dataset Height, and a number of 19 and 23 substudies for datasets Diameter and Survival, respectively. Each substudy was classified in one of four texture subsets using the USDA classification system (Soil Survey Division Staff, 1993): sand (sand, loamy sand, sandy loam), silt (silt, silt loam), loam (loam, sandy clay loam, silt clay loam) and clay (clay, silty clay, sandy clay, clay loam). Due to a lack of detailed information on soil texture, a few substudies were assigned to more than one texture subset. For instance, when soil texture information mentioned sandy loam-silt loam, the soil was classified as both sand and silt. The examined tree species were subdivided into two functional tree groups: deciduous broadleaved species and evergreen coniferous species. Taking the morphological and functional differences between these two groups into account, we hypothesized that there might also be a difference in response to soil compaction. It should be noted that eight of the 14 examined species (around $65 \%$ of the substudies for each dataset) were intolerant to shade, five displayed intermediate shade tolerance (around 33\% of the substudies) and only one species was shade tolerant ( $<5 \%$ of the substudies) (cf USDA \& NRCS, 2010) (see Appendix A).

In each substudy, part of the area was compacted with forestry machines, tractors or a rolling vibrator and another part was left untreated and was thus not influenced by the machines. As an indication of the soil compaction degree, most articles mentioned information on soil bulk density $(68 \%, 79 \%, 70 \%$ of substudies for Height, Diameter, and Survival, respectively). Information on other abiotic variables (e.g., penetration resistance, $\mathrm{CO}_{2}$ efflux, etc) was not considered due to the limited number of substudies for which these characteristics were available. The response ratio of bulk density $\left(R R_{\text {dens }}\right)$ of each substudy was determined as the ratio of the mean bulk density on the compacted area for that substudy to the mean bulk density on the uncompacted area for that substudy:

$$
R R_{\text {dens }}=\frac{\text { bulk density on compacted area }}{\text { bulk density on uncompacted area }}
$$

The bulk density on the uncompacted area is termed Contrdens hereafter. If no compaction took place, $\mathrm{RR}_{\mathrm{dens}}$ is equal to one, but the ratio increases with the compaction degree. If information on the compaction degree was available for several soil depths, only the results obtained in depth interval 10-20 cm were used in further analyses. This depth interval normally holds relatively high root densities and compaction degrees are often higher compared to depth interval 0-10 cm, thus giving a better indication of the soil impact (e.g., Ampoorter, Goris, Cornelis \& Verheyen, 2007). Period represents the number of years between the start of the measurement period (date of planting 
for planted seedlings, date of harvest or compaction treatment for resprouts and natural regeneration) and the final measurements.

\section{Response variables}

In all substudies, on both the uncompacted and the compacted area, an equal number of saplings with similar initial height and diameter were planted or selected from natural regeneration or resprouts. After a certain period (see Appendix A), various combinations of height, diameter, and survival were measured. In order to evaluate the response of height growth to soil compaction, the response ratio $\mathrm{RR}_{\text {height }}$ was calculated for each substudy as the ratio of the mean total height on the compacted area for that substudy to the mean total height on the uncompacted area for that substudy:

$$
R R_{\text {height }}=\frac{\text { total height on compacted area }}{\text { total height on uncompacted area }}
$$

Response ratios for diameter $\left(R R_{\text {diam }}\right)$ and survival $\left(R R_{\text {surv }}\right)$ were calculated in a similar way. One substudy was omitted from the survival dataset (Tan, Curran, Chang \& Maynard, 2009) since it was an extreme outlier (survival rate on the compacted soil 2-3 times survival rate on the uncompacted soil).

\section{Analysis}

Hedges, Gurevitch \& Curtis (1999) stated that a good and balanced meta-analysis requires three basic statistics, namely the mean of the response variable, a measure of the variance, and the number of replicates. Their method determines weighted mean response ratios and correlation coefficients, taking the number of replications and the variance of each substudy into account. Giving greater weights to experiments whose estimates have greater statistical precision (smaller standard error) increases the precision and thus reliability of the combined estimate. A detailed description of these analyses is given in Hedges et al. (1999). In the present study the available information on the number of replicates and variances shows strong variation and the use of the techniques of Hedges et al. (1999) would thus be beneficial. However, a lot of the selected articles lacked information on the above mentioned basic statistics and only for dataset Height an adequate number of studies (7 studies containing 20 substudies in total) contained the necessary information.

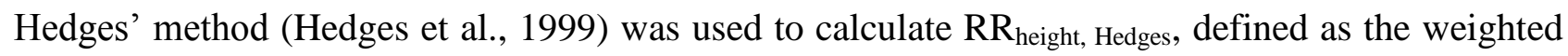
mean of the natural logarithm of $\mathrm{RR}_{\text {height }}$ (value equals zero in case no difference exists between compacted and uncompacted area). The weighted Pearson correlation coefficient between $\mathrm{RR}_{\text {height, }}$ Hedges and $\mathrm{RR}_{\text {dens }}$ was based on 4 of these studies (containing 13 substudies) as the rest lacked information on the bulk density increase caused by the compaction treatments.

The techniques of Hedges et al. (1999) could thus not be applied to most substudies in the datasets on diameter growth and survival and several substudies in dataset Height. Unweighted analyses are not as accurate as the weighted analysis of Hedges et al. (1999) but may provide an indication of the mean responses to soil compaction. Resampling Stats v. 4.0 (http://www.resample.com) was used to calculate unweighted mean values and $95 \%$ bootstrapping confidence intervals (dataset resampled 1500 times, randomly and with replacement) of $\mathrm{RR}_{\text {height }}$, $\mathrm{RR}_{\text {diam }}, \mathrm{RR}_{\text {surv }}$ and $\mathrm{RR}_{\text {dens }}$ for all substudies together and for the functional tree groups and textures separately. 
The relative importance of the predictor variables functional tree group, texture, $R_{\text {dens }}$, Contrdens and period on $\mathrm{RR}_{\text {height }}, \mathrm{RR}_{\text {diam }}$ and $\mathrm{RR}_{\text {surv }}$, was tested with multilevel models in $\mathrm{R} 2.11 .1$ (R Development Core Team, 2010). A random effect term study was added to the models to address the likelihood that substudies obtained from the same study share autocorrelated characteristics. First, a null model was constructed containing only the random effect term, and the intraclass

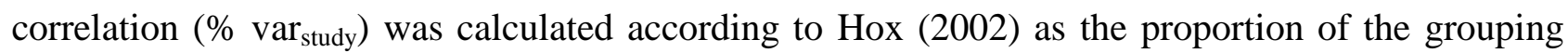
level variance $\left(\sigma_{\text {stwdy }}^{2}\right)$ to the total variance $\left(\sigma_{\text {stwdy }}^{2}+\sigma_{\text {residwals }}^{2}\right)$ :

$$
\% v_{\text {var }} r_{\text {atudy }}=\left(\frac{\sigma_{\text {stwdy }}^{2}}{\sigma_{\text {stwdy }}^{2}+\sigma_{\text {residwals }}^{2}}\right) \times 100
$$

Next, the null model was compared with a model that included one of the predictor variables. Based on the $-2 \log$ Likelihood information criterion (i.e., deviance; Hox, 2002) the significance of each predictor variable was tested ( $\chi^{2}$ test statistic; Zuur, Ieno, Walker, Saveliev \& Smith, 2009). To avoid overfitting and for model simplification, only variables with $\mathrm{p}$-value $<0.05$ were considered for the final multilevel model. Subsequently, the remaining significant predictors were added one-by-one to the model with the lowest deviance containing only one predictor. If the deviance decreased significantly ( $\chi^{2}$ test statistic with likelihood ratio test), this procedure was repeated.

Finally, we estimated the proportion of the variation explained by adding the predictor variables to the null model. For that purpose, the ratio of the difference in residuals between the null model $\left(\sigma_{\text {manl }}^{2}\right)$ and the final model $\left(\sigma_{\text {final }}^{2}\right)$ over the residuals of the null model (Hox, 2002) was calculated:

$$
\text { \% remaining var } \text { final }=\left(\frac{\sigma_{\text {mull }}^{2}-\sigma_{\text {final }}^{2}}{\sigma_{\text {mull }}^{2}}\right) \times 100
$$

\section{Results}

In general, mean $\mathrm{RR}_{\text {dens }}$ values were significantly larger than one for the three response variables (Fig. 1). Response variable Diameter even had a mean $R_{\text {dens }}$ significantly higher than 1.15. Mean $R_{\text {height }}\left(0.92<\right.$ [mean $\left.\left.R_{\text {height }}=0.99\right]<1.07\right), R_{\text {diam }}\left(0.86<\right.$ mean $\left.R_{\text {diam }}=1.05\right]<$ $1.26)$ and $R_{\text {surv }}\left(0.90<\left[\right.\right.$ mean $\left.\left.R R_{\text {surv }}=0.97\right]<1.04\right)$, calculated for all subsets together, were not significantly different from one. Mean $R_{\text {height }}, R_{\text {diam }}$ and $R_{\text {surv }}$ and corresponding bootstrapping confidence intervals for subsets Broadleaved, Conifer, Sand, Loam, Silt and Clay are represented in Fig. 2. Only three of these mean values were significantly different from one (silt in dataset Height; silt and loam in dataset Survival). Large interstudy variation and thus relatively wide confidence intervals were present. 


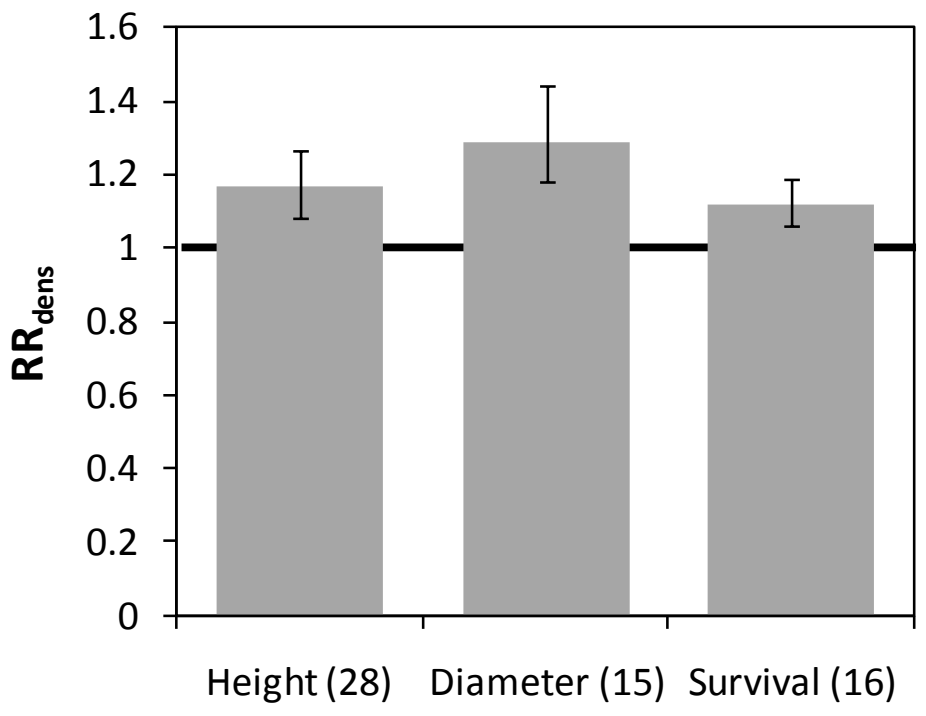

Fig. 1. Mean $R R$ of bulk density ( $R R_{\text {dens }}$ ) for datasets of height, diameter and survival of tree saplings (and 95\% bootstrapping confidence interval). RR stands for the response ratio, that is the ratio of the value on the compacted area to the value on the uncompacted area. If $R R=1$, no difference was found between the two areas. The number of substudies that were used to calculate mean $\mathbf{R} \mathbf{R}_{\text {dens }}$ is indicated between brackets.

Looking at $\mathrm{RR}_{\text {height }}$ (Fig. 2), only the mean value for silty soils was significantly lower than 1, indicating lower height growth following compaction. Comparing texture groups, $\mathrm{RR}_{\text {height }}$ for silt $\left(0.76<\left[R R_{\text {height, silt }}=0.87\right]<0.97\right)$ was significantly lower than $R R_{\text {height }}$ for sand $\left(0.99<\left[R R_{\text {height, }}\right.\right.$ sand $=1.12]<1.33)$. No significant difference was seen between functional tree groups. Multilevel modelling indicated that the random factor study determined $79.3 \%$ of the variance in $\mathrm{RR}_{\text {height }}$ and that none of the predictor variables significantly influenced $R_{R}$ height (Table 1). Seven studies (representing 20 substudies) in the height dataset gave full information on number of replications and a measure of variance, and thus met the requirements of Hedges et al. (1999) for complete analysis. In contrast with the unweighted mean $\mathrm{RR}_{\text {height }}$ for all subsets together that was not significantly different from $1\left(0.99<\left[R R_{\text {height, sand }}=1.12\right]<1.33\right)$, the weighted mean $R_{\text {height,Hedges }}$ for all subsets together was significantly lower than zero $(-0.037 \pm 0.015)$ and thus indicated slower

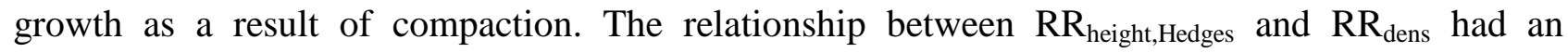
insignificant weighted Pearson correlation coefficient of 0.47 . This was in accordance with the previous results (i.e., no significant effect of the predictor variables on $\mathrm{RR}_{\text {height}}$ ).

Concerning $\mathrm{RR}_{\text {diam }}$, none of the subsets showed a mean value significantly different from 1 (Fig. 2). Although the difference was insignificant, mean RRdiam for silt and clay were clearly lower compared to the values for sand and loam. Multilevel modelling indicated that $95.6 \%$ of the variance in $\mathrm{RR}_{\text {diam }}$ was explained by the random factor study and no significant influence of the predictor variables was detected (Table 1).

Results for $\mathrm{RR}_{\text {surv }}$ were predominantly insignificant (Fig. 2). Mean $\mathrm{RR}_{\text {surv }}$ for silt (and clay to a smaller extent) indicated significantly lower survival on the compacted soil while compaction on loamy soils seemed to be beneficial to survival of tree seedlings. Results of multilevel modelling indicated that $38.4 \%$ of the variance in $\mathrm{RR}_{\text {surv }}$ was determined by the random factor study and that none of the predictor variables had a significant influence on $\mathrm{RR}_{\text {surv }}$ (Table 1). 

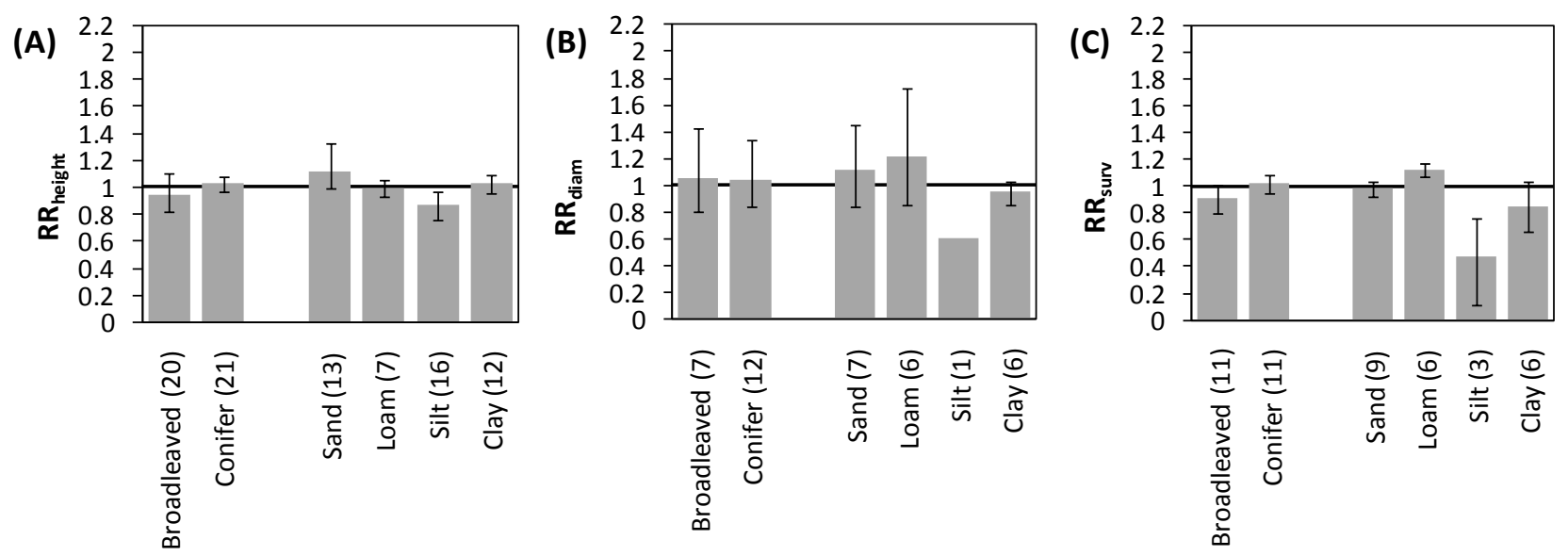

Fig. 2. Effects of functional tree group (broadleaved/conifer) and texture (sand, loam, silt, clay) on the mean $R R$ of height $\left(\mathbf{R R}_{\text {height }}\right)(\mathrm{A})$, diameter $\left(\mathbf{R} \mathbf{R}_{\text {diam }}\right)(\mathbf{B})$ and survival $\left(\mathbf{R} \mathbf{R}_{\text {surv }}\right)(\mathbf{C})$ of tree saplings (and 95\% bootstrapping confidence interval). RR stands for the response ratio, that is the ratio of the value on the compacted area to the value on the uncompacted area. If $R R=1$, no difference was found between the two areas. The number of substudies that were used to calculate mean $\mathbf{R R}_{\text {height }}, \mathbf{R} \mathbf{R}_{\text {diam }}$ or $\mathbf{R R}_{\text {surv }}$ is indicated between brackets.

Table 1. Response of height growth $\left(R R_{\text {height }}\right)$, diameter growth $\left(R R_{\text {diam }}\right)$ and survival $\left(R R_{\text {surv }}\right)$ to five predictor variables: $R R_{\text {dens }}$ (RR of bulk density), Contrdens (bulk density on the uncompacted area), functional tree group (broadleaved/conifer), texture (sand/silt/loam/clay) and period (the number of years between initial and end measurements). Reported results are derived from multilevel modelling with one predictor variable and the factor study as a random effect term. The $\chi^{2}$ values are derived from likelihood ratio tests. Significant effects are depicted in bold.

\begin{tabular}{lcccccc}
\hline Predictor variable & \multicolumn{2}{c}{$\mathbf{R R}_{\text {height }}$} & \multicolumn{2}{c}{$\mathbf{R R}_{\text {diam }}$} & \multicolumn{2}{c}{$\mathbf{R R}_{\text {surv }}$} \\
& $\chi^{2}$ & $\mathrm{p}$-value & $\chi^{2}$ & $\mathrm{p}$-value & $\chi^{\mathbf{2}}$ & $\mathrm{p}$-value \\
\hline $\mathbf{R R}_{\text {dens }}$ & 1.332 & 0.195 & 0.001 & 0.232 & 3.728 & 0.054 \\
Contrdens & 1.679 & 0.249 & 1.428 & 0.982 & 0.147 & 0.701 \\
Functional tree group & 0.111 & 0.739 & 1.687 & 0.194 & 1.418 & 0.234 \\
Texture & 0.647 & 0.421 & 1.423 & 0.233 & 1.310 & 0.252 \\
Period & 0.005 & 0.945 & 1.353 & 0.245 & 0.976 & 0.323 \\
\hline
\end{tabular}

RR stands for the response ratio, that is the ratio of the value on the compacted area to the value on the uncompacted area.

\section{Discussion}

The increase in bulk density showed that an overall significant degree of compaction was present. The experimental set-up of the selected articles was thus appropriate to examine the effect of soil compaction on growth and survival. Moreover, for some subsets, bulk density increased by more than 15\%. This means that soil compaction degrees could be detrimental for root growth according to the suggestions of Powers et al. (1998).

The application of Hedges' method (Hedges et al., 1999) revealed that, in general, soil compaction significantly hampered height growth. However, this result should be interpreted with caution, as it is based on a small number of study results. Moreover, most unweighted RR were not significantly different from one, except for silt soils, and multilevel modelling did not indicate a significant effect of texture. Results only indicated that height growth, diameter growth, and survival were slightly hampered by soil compaction on silty soils, and survival to a smaller extent 
also on clay soils. On coarser-textured sandy and loamy soils growth and survival were not affected or rather improved by soil compaction, although compaction degrees were higher than on silt and clay soils. As was mentioned in the introduction, soil compaction induces a lot of soil structural and physical changes, such as higher penetration resistance, lower hydraulic conductivity, and decreasing amount of soil available water. These changes may negatively influence tree saplings, as was found on the silt and clay soils. However, according to Dexter (2004) and Lacey \& Ryan (2000), soil compaction not always implies negative outcomes for soil quality. Undisturbed coarsetextured soils contain many macropores that are too wide to hold water against gravitational forces. This implies a low water retention capacity and thus a low amount of plant available water. Compaction decreases the mean pore size and thus leads to better water retention. As the low amount of plant available water is one of the limiting factors for growth of herbs and trees on coarse-textured soils, this higher water availability may have compensated the negative effects of soil compaction.

A negative correlation was expected between the response ratios of bulk density $\left(R_{\mathrm{dens}}\right)$ on the one hand and the response ratios of height, diameter, and survival on the other. Namely, higher compaction degrees and thus greater changes in soil chemical and physical characteristics were expected to impose a higher stress on saplings, leading to more retarded growth and survival. However, information on bulk density increase lacked for several substudies. For the remaining substudies with complete information, neither the use of multilevel models nor Hedges' method (in case of height) revealed a significant correlation between the soil compaction degree and responses of growth and survival. Namely, at both low and high compaction degrees, $\mathrm{RR}_{\text {height }}, \mathrm{RR}_{\text {diam }}$ and $\mathrm{RR}_{\text {surv }}$ varied widely around 1 , a threshold that indicates no response to soil compaction. These response ratios were also assumed to decrease with increasing value of period. The longer the period in which growth and survival were monitored, the longer compaction could have exerted a negative influence on growth and survival. However, relationships between $R_{\text {height }}, R_{\text {diam }}$, and $\mathrm{RR}_{\text {surv }}$ on the one hand and period on the other were also insignificant, again due to high variation and the low number of substudies.

Wide confidence intervals for biotic responses indicated that the effects of soil compaction were ambiguous. Averaged responses of growth and survival predominantly showed no significant effect of soil compaction on saplings. This shows that the effects of soil compaction were not always detrimental for tree saplings but depended, among other variables, on tree species (Miller, Scott \& Hazard, 1996; Kabzems, 2000) or compaction severity (Ehlers, Popke, Hesse \& Bohm, 1983). It must be remarked that only a limited number of (sub)studies could be included in the dataset, especially for the weighted analyses. The higher the number of substudies with complete information that are available, the more reliable are the results that are obtained, and the more general are the conclusions that are drawn. It is thus crucial for future publications to give attention to the detailed report of basic statistics so that the results can be used in meta-analyses.

It is possible that the long-term effect on tree saplings or the effect on adult trees differs from the effect on tree saplings in the first years after soil was compacted. This should be examined through long-term monitoring and examination of the effect of soil compaction on established, adult trees. Moreover, most of the examined tree species are not shade tolerant. This is not surprising as most studies were performed on clearcut areas with very high light availabilities where shade tolerant tree species that are adapted to low light levels are generally not successful. However, this 
means that no conclusions could be drawn concerning the tolerance to soil compaction of shade tolerant species. It is not certain that the sensitivity to soil compaction is similar for both groups of tree species. For example, compaction is often accompanied by a reduction of the plant available water amount (and thus likely increases drought stress; Ballard 2000). Niinemets \& Valladares (2006) examined 806 temperate shrub and tree species and observed significant negative correlations among shade and drought tolerance, with less than $10 \%$ of the examined species being relatively tolerant to both stresses simultaneously. Small \& McCarthy (2002) showed severe growth and biomass reductions for Osmorhiza claytonii, a shade-tolerant perennial, after soil compaction. Further research is needed to draw general conclusions concerning the effect of soil compaction on seedling performance of shade tolerant tree species.

\section{Conclusions and recommendations}

The results of the unweighted meta-analysis showed no clear influence of soil compaction on growth and survival. This was probably due to high variation in the dataset concerning tree species, compaction degrees, etc., and the low number of studies that could be included in the dataset. Yet, although differences were overall insignificant (except for silt) and no significant effect of texture was detected, results showed small negative effects of soil compaction on finetextured soils and more beneficial effects on coarser-textured soils. Moreover, the weighted analysis indicated an overall negative effect on height growth. This analysis was, however, based on a very limited number of studies and should be interpreted with caution.

Measurements were performed after standard harvests or experiments were set up intending to mimic traffic intensities or compaction degrees of standard harvests. Several studies indicated that most of the total compaction is caused by the first machine pass(es) (e.g., Brais \& Camiré). In many regions machines are not restricted to permanent skid trails and as a result, a large part of the forest area is compacted. Although no clear conclusions could be drawn concerning the impact of soil compaction on growth and survival of saplings, several study results did show negative effects at the induced compaction degrees. Sustainable forest management requires that both the degree and spatial extent of soil compaction due to mechanized forest operations are minimized, for example by reducing the soil contact pressure of the machine or by using permanent skid trails, to prevent a decrease of site productivity.

Future research should focus on shade tolerant tree species and older trees as information on sensitivity to soil compaction of these species and higher age classes is lacking. Finally, this study clearly showed that more attention should be given to the report of important basic characteristics (number of replications, measurement variation, etc) in order to make results more reliable, draw conclusions that are more universally applicable, and make relationships stronger.

\section{Acknowledgements}

This work was supported by the Flemish government through a grant of the IWT (Institute for the Promotion of Innovation by Science and Technology in Flanders) for Evy Ampoorter, a grant of the FWO (Research Foundation-Flanders) for Pieter De Frenne and ANB (Agency for Nature and Forest). The authors wish to express their appreciation to the authors of the studies, used in the meta-analysis, for the provision of lacking data. 


\section{References}

Agrawal, R.P. (1991). Water and nutrient management in sandy soils by compaction. Soil \& Tillage Research, 19, 121-130.

Alameda, D., \& Villar, R. (2009). Moderate soil compaction: implications on growth and architecture in seedlings of 17 woody plant species. Soil \& Tillage Research, 103, 325-331.

Ampoorter, E., Goris, R., Cornelis, W.M., \& Verheyen, K. (2007). Impact of mechanized logging on compaction status of sandy forest soils. Forest Ecology and Management, 241, 162-174.

Ares, A., Terry, T.A., Miller, R.E., Anderson, H.W., \& Flaming, B.L. (2005). Ground-based forest harvesting effects on soil physical properties and douglas-fir growth. Soil Science Society of America Journal, 69, 1822-1832.

Arshad, M.A., Lowery, B., \& Grossman, B. (1996). Physical tests for monitoring soil quality. In: J.W. Doran \& A.J. Jones (Eds.), Methods for assessing soil quality. Soil Science Society of America. Special Publication 49 (pp. 123-143). Madison: SSSA.

Aust, W.M., Burger, J.A., Carter, E.A., Preston, D.P., \& Patterson, S.C. (1998). Visually determined soil disturbance classes used as indices of forest harvesting disturbance. Southern Journal of Applied Forestry, 22, 245-250.

Balbuena, R., Mac Donagh, P., Marquina, J., Jorajuria, D., Terminiello, A., \& Claverie, J. (2002). Wheel traffic influence on poplar regeneration and grass yield. Biosystems Engineering, 81, 379-384.

Ballard, T.M. (2000). Impacts of forest management on northern forest soils. Forest Ecology Management, 133, 37-42.

Bates, P.C., Blinn, C.R., \& Alm, A.A. (1993). Harvesting impacts on quaking aspen regeneration in northern Minnesota. Canadian Journal of Forest Research, 23, 2403-2412.

Benthaus, M., \& Matthies, D. (1993). Regeneration befahrener Waldböden. Allgemeine Forstzeitschrift, 48, 448-451.

Blumfield, T.J., Xu, Z.H., \& Chen, C. (2005). Mineral nitrogen dynamics following soil compaction and cultivation during hoop pine plantation establishment. Forest Ecology \& Management, 204, 129-135.

Bockheim, J.G., Park, H., \& Gallagher, J. (2005). Genotypic variation and recovery of Populus tremuloides from biomass removal and compaction in northern Wisconsin, USA. Canadian Journal of Forest Research, 35, 221-228.

Brais, S. (2001). Persistence of soil compaction and effects on seedling growth in Northwestern Quebec. Soil Science Society of America Journal, 65, 1263-1271.

Bulmer, C.E., \& Simpson, D.G. (2005). Soil compaction and water content as factors affecting the growth of lodgepole pine seedlings on sandy clay loam soil. Canadian Journal of Soil Science, 85, 667-679.

Carter, M.C., Dean, T.J., Wang, Z., \& Newbold, R.A. (2006). Impact of harvesting and postharvest treatments on soil bulk density, soil strength, and early growth of Pinus taeda in the Gulf Coastal Plain: a Long-Term Soil Productivity affiliated study. Canadian Journal of Forest Research, 36, 601-614.

Cheatle, R.J. (1991). Tree growth on a compacted oxisol. Soil \& Tillage Research, 19, 331-344.

Cullen, S.J., Montagne, C., \& Ferguson, H. (1991). Timber harvest trafficking and soil compaction in Western Montana. Soil Science Society of America Journal, 55, 1416-1421. 
Da Silva, S.R., de Barros, N.F., da Costa, L.M., \& Leite, F.P. (2008). Soil compaction and Eucalyptus growth in response to forwarder traffic intensity and load. Revista Brasileira de Ciência do Solo, 32, 921-932.

Dexter, A.R. (2004). Soil physical quality. Part I. Theory, effects of soil texture, density, and organic matter, and effects on root growth. Geoderma, 120, 201-214.

Ehlers, W., Popke, V., Hesse, F., \& Bohm, W. (1983). Penetration resistance and root growth of oats in tilled and untilled loam soil. Soil \& Tillage Research, 3, 261-275.

Fleming, R.L., Powers, R.F., Foster, N.W., Kranabetter, J.M., Scott, D.A., Ponder, F.Jr., Berch, S., Chapman, W.K., Kabzems, R.D., Ludovici, K.H., Morris, D.M., Page-Dumroese, D.S., Sanborn, P.T., Sanchez, F.G., Stone, D.M., \& Tiarks, A.E. (2006). Effects of organic matter removal, soil compaction, and vegetation control on 5-year seedling performance: a regional comparison of Long-Term Soil Productivity sites. Canadian Journal of Forest Research, 36, 529-550.

Gebauer, R., \& Martinková, M. (2005). Effects of pressure on the root systems of Norway spruce plants (Picea abies [L.] Karst.). Journal of Forest Science, 51, 268-275.

Gomez, A., Powers, R.F., Singer, M.J., \& Horwath, W.R. (2002). Soil compaction effects on growth of young ponderosa pine following litter removal in California's Sierra Nevada. Soil Science Society of America Journal, 66, 1334-1343.

Grant, R.F. (1993). Simulation model of soil compaction and root growth. II. Model performance and validation. Plant \& Soil, 150, 15-24.

Greacen, E.L., \& Sands, R. (1980). Compaction of forest soils. A review. Australian Journal of Soil Research, 18, 163-189.

Harvey, B., \& Brais, S. (2002). Effects of mechanized careful logging on natural regeneration and vegetation competition in the southeastern Canadian boreal forest. Canadian Journal of Forest Research, 32, 653-666.

Hedges, L.V., Gurevitch, J., \& Curtis, P.S. (1999). The meta-analysis of response ratios in experimental ecology. Ecology, 80, 1150-1156.

Heninger, R., Scott, W., Dobkowski, A., Miller, R., Anderson, H., \& Duke, S. (2002). Soil disturbance and 10-year growth response of coast Douglas-fir on nontilled and tilled skid trails in the Oregon Cascades. Canadian Journal of Forest Research, 32, 233-246.

Hox, J.J. (2002). Multilevel analysis. Techniques and applications. ( $1^{\text {st }}$ ed.). London: Lawrence Erlbaum Associates.

Jordan, D., Hubbard, V.C., Ponder, F.Jr., \& Berry, E.C. (1999). Effect of soil compaction and organic matter removal on two earthworm populations and some soil properties in a hardwood forest. Pedobiologia, 43, 802-807.

Kabzems, R. (2000). Fourth year responses of aspen and white spruce; the BWBS Long-Term Soil Productivity Study. Forest Service British Columbia, Note \#LTSPS-02.

Kabzems, R., \& Haeussler, S. (2005). Soil properties, aspen, and white spruce responses 5 years after organic matter removal and compaction treatments. Canadian Journal of Forest Research, 35, 2045-2055.

Kamaluddin, M., Chang, S.X., Curran, M.P., \& Zwiazek, J.J. (2005). Soil compaction and forest floor removal affect early growth and physiology of lodgepole pine and douglas-fir in British Columbia. Forest Science, 51, 513-521.

Kara, O., \& Bolat, I. (2007). Influence of soil compaction on microfungal community structure in two soil types in Bartin Province, Turkey. Journal of Basic Microbiology, 47, 394-399. 
Kottek, M., Grieser, J., Beck, C., Rudolf, B., \& Rubel, F. (2006). World map of the Köppen-Geiger climate classification updated. Meteorologische Zeitschrift, 15, 259-263.

Kozlowski, T.T. (1999). Soil compaction and growth of woody plants. Scandinavian Journal of Forest Research, 14, 596-619.

Kranabetter, J.M., Sanborn, P., Chapman, B.K., \& Dube, S. (2006). The contrasting response to soil disturbance between lodgepole pine and hybrid white spruce in subboreal forests. Soil Science Society of America Journal, 70, 1591-1599.

Lacey, S.T., \& Ryan, P.J. (2000). Cumulative management impacts on soil physical properties and early growth of Pinus radiata. Forest Ecology \& Management, 138, 321-333.

Ludovici, K.H. (2008). Compacting coastal plain soils changes midrotation loblolly pine allometry by reducing root biomass. Canadian Journal of Forest Research, 38, 2169-2176.

Miller, R.E., Scott, W., \& Hazard, J.W. (1996). Soil compaction and conifer growth after tractor yarding at three coastal Washington locations. Canadian Journal of Forest Research, 26, 225-236.

Murphy, G., Firth, J.G., \& Skinner, M.F. (1997). Soil disturbance effects of Pinus radiata growth during the first 11 years. New Zealnd Forestry, 42, 27-30.

Nabe-Nielsen, J., Severiche, W., Fredericksen, T., \& Nabe-Nielsen, L.I. (2007). Timber tree regeneration along abandoned logging roads in a tropical Bolivian forest. New Forests, 34, $31-40$.

Niinemets, Ü., \& Valladares, F. (2006). Tolerance to shade, drought, and waterlogging of temperate northern hemisphere trees and shrubs. Ecological Monographs, 76, 521-547.

Perry, T.O. (1964). Soil compaction and loblolly pine growth. Tree Planters' Notes, 67, 9-9.

Ponder, F.Jr., Alley, D.E., Jordan, D., Swartz, M.E., \& Hubbard, V.C. (1999). Impacts of harvest intensity and soil disturbance on early tree growth and earthworm populations in a Missouri Ozark forest. Proceedings of the $12^{\text {th }}$ central hardwood forest conference, Lexington, $K Y$.

Powers, R.F. (2006). Long-Term Soil Productivity: genesis of the concept and principles behind the program. Canadian Journal of Forest Research 36, 519-528.

Powers, R.F., Tiarks, A.E., \& Boyle, J.R. (1998). Assessing soil quality: practicable standards for sustainable forest productivity in the United States. In: M.B. Adams, E.A. Davidson, \& K. Ramakrishna (eds.), The contribution of soil science to the development of an implementation of criteria and indicators of sustainable forest management. Soil Science Society of America Journal. Special Publication 53 (pp. 52-80). Madison: SSSA.

Puettmann, K.J., D’Amato, A.W., Arikian, M., \& Zasada, J.C. (2008). Spatial impacts of soil disturbance and residual overstory on density and growth of regenerating aspen. Forest Ecology \& Management, 256, 2110-2120.

R Development Core Team (2010), R: A language and environment for statistical computing. $R$ Foundation for Statistical Computing. Vienna: R Foundation for Statistical Computing.

Rhoades, C.C., Brosi, S.L., Dattilo, A.J., \& Vincelli, P. (2003). Effect of soil compaction and moisture on incidence of phytophthora root rot on American chestnut (Castanea dentate) seedlings. Forest Ecology \& Management, 184, 47-54.

Sanchez, F.G., Scott, D.A., \& Ludovici, K.H. (2006). Negligible effects of severe organic matter removal and soil compaction on loblolly pine growth over 10 years. Forest Ecology \& Management, 227, 145-154. 
Simcock, R.C., Parfitt, R.L., Skinner, M.F., \& Dando, J., \& Graham, J.D. (2006). The effects of soil compaction and fertilizer application on the establishment and growth of Pinus radiata. Canadian Journal of Forest Research, 36, 1077-1086.

Small, C.J., \& McCarthy, B.C. (2002). Effects of simulated post-harvest light availability and soil compaction on deciduous forest herbs. Canadian Journal of Forest Research, 32, 17531762 .

Smith, C.W. (2003). Does soil compaction on harvesting extraction roads affect long-term productivity of Eucalyptus plantations in Zululand, South Africa? Southern African Forestry Journal, 199, 41-54.

Soil Survey Division Staff (1993). Soil survey manual, US Department of Agriculture Handbook 18. ( $1^{\text {st }}$ ed.). Washington: US Government Printing Office.

Startsev, A.D., \& McNabb, D.H. (2009). Effects of compaction on aeration and morphology of boreal forest soils in Alberta, Canada. Canadian Journal of Soil Science, 89, 45-56.

Stone, D.M., \& Elioff, J.D. (1998). Soil properties and aspen development five years after compaction and forest floor removal. Canadian Journal of Soil Science, 78, 51-58.

Stone, D.M., \& Kabzems, R. (2002). Aspen development on similar soils in Minnesota and British Columbia after compaction and forest floor removal. The Forestry Chronicle, 78, 886-891.

Tan, X., \& Chang, S.X. (2007). Soil compaction and forest litter amendment affect carbon and net nitrogen mineralization in a boreal forest soil. Soil \& Tillage Research, 93, 77-86.

Tan, X., Curran, M., Chang, S., \& Maynard, D. (2009). Early growth responses of lodgepole pine and douglas-fir to soil compaction, organic matter removal, and rehabilitation treatments in southeastern British Columbia. Forest Science, 55, 210-220.

USDA, NRCS (2010). The Plants Database (http://plants.usda.gov, 17 September 2010). National Plant Data Center, Baton Rouge, LA.

Whalley, W.R., Dumitru, E., \& Dexter, A.R. (1995). Biological effects of soil compaction. Soil \& Tillage Research, 35, 53-68.

Zenner, E.K., \& Berger, A.L. (2008). Influence of skidder traffic and canopy removal intensities on the ground flora in a clearcut-reserves northern hardwood stand in Minnesota, USA. Forest Ecology \& Management, 256, 1785-1794.

Zuur, A.F., Ieno, E.N., Walker, N.J., Saveliev, A.A., \& Smith, G.M. (2009). Mixed effects models and extensions in ecology with R ( $1^{\text {st }}$ ed.). New York: Springer. 


\section{Appendix A}

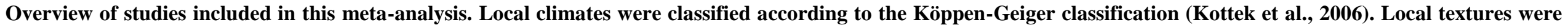

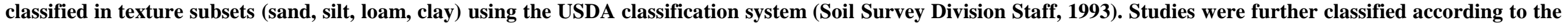

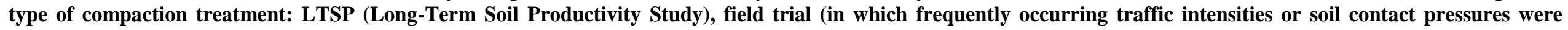

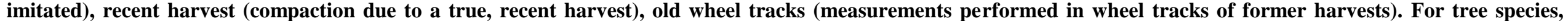

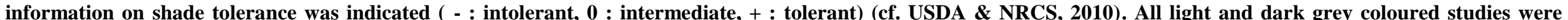

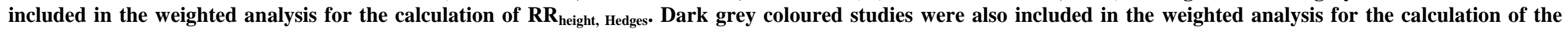
weighted Pearson correlation coefficient between $\mathbf{R R}_{\text {height, Hedges }}$ and $\mathbf{R} \mathbf{R}_{\text {dens }}$.

\begin{tabular}{|c|c|c|c|c|c|c|c|c|c|c|c|}
\hline \multirow{2}{*}{$\begin{array}{l}\text { Article } \\
\text { (year of publication) }\end{array}$} & \multirow[t]{2}{*}{ Location } & \multirow{2}{*}{$\begin{array}{c}\text { Köppen- } \\
\text { Geiger } \\
\text { classification }\end{array}$} & \multirow{2}{*}{$\begin{array}{l}\text { Texture } \\
\text { subset }\end{array}$} & \multirow{2}{*}{$\begin{array}{c}\text { Type of } \\
\text { compaction } \\
\text { treatment } \\
\end{array}$} & \multirow{2}{*}{$\begin{array}{c}\text { Tree species } \\
\text { (with shade } \\
\text { tolerance) }\end{array}$} & \multirow{2}{*}{$\begin{array}{l}\text { Type of } \\
\text { sapling }\end{array}$} & \multirow{2}{*}{$\begin{array}{c}\text { Measurement } \\
\text { year }\end{array}$} & \multicolumn{3}{|c|}{ Number of substudies } & \multirow{2}{*}{ \# locations } \\
\hline & & & & & & & & Height & Diameter & Survival & \\
\hline $\begin{array}{l}\text { Ares, Terry, Miller, } \\
\text { Anderson, \& } \\
\text { Flaming }(\mathbf{2 0 0 5})\end{array}$ & $\begin{array}{c}\text { Coastal range of } \\
\text { Washington State }\end{array}$ & Csb & Clay & LTSP & $\begin{array}{l}\text { Pseudotsuga } \\
\text { menziesii }(0)\end{array}$ & $\begin{array}{l}\text { planted (at } \\
\text { age } 2 \text { years) }\end{array}$ & $\begin{array}{l}4 \text { years after } \\
\text { planting }\end{array}$ & 1 & 1 & & 1 \\
\hline $\begin{array}{l}\text { Balbuena, Mac } \\
\text { Donagh, Marquina, } \\
\text { Jorajuria, } \\
\text { Terminiello, et al. } \\
(2002)\end{array}$ & $\begin{array}{c}\text { Buenos Aires } \\
\text { State, Argentina }\end{array}$ & $\mathrm{Cfa}$ & Clay & field trial & Populus deltoides (-) & resprouts & $\begin{array}{l}1 \text { year after } \\
\text { compaction }\end{array}$ & 3 & & 3 & 1 \\
\hline $\begin{array}{l}\text { Bates, Blinn \& Alm } \\
\text { (1993) }\end{array}$ & $\begin{array}{c}\text { Northern } \\
\text { Minnesota }\end{array}$ & Dfb (mainly) & silt & $\begin{array}{c}\text { recent } \\
\text { harvest }\end{array}$ & $\begin{array}{c}\text { Populus tremuloides } \\
(-)\end{array}$ & $\begin{array}{c}\text { natural } \\
\text { regeneration }\end{array}$ & $\begin{array}{l}1 \text { year after } \\
\text { compaction }\end{array}$ & 4 & & & 1 \\
\hline $\begin{array}{l}\text { Bockheim, Park, \& } \\
\text { Callagher (2005) }\end{array}$ & $\begin{array}{l}\text { Northwestern } \\
\text { Wisconsin }\end{array}$ & $\mathrm{Dfb}$ & sand & field trial & $\begin{array}{c}\text { Populus tremuloides } \\
(-)\end{array}$ & $\begin{array}{c}\text { natural } \\
\text { regeneration }\end{array}$ & $\begin{array}{l}8 \text { years after } \\
\text { compaction }\end{array}$ & & 1 & & 1 \\
\hline Brais (2001) & $\begin{array}{l}\text { Gulf Coastal Plain } \\
\text { of USA }\end{array}$ & $\mathrm{Dfb}$ & $\begin{array}{l}\text { Clay } \\
\text { Sand } \\
\text { Sand }\end{array}$ & field trial & $\begin{array}{c}\text { Picea glauca }(0) \\
\text { Picea mariana }(+) \\
\text { Pinus banksiana (-) }\end{array}$ & $\begin{array}{l}\text { planted (at } \\
\text { age } 2 \text { years) }\end{array}$ & $\begin{array}{l}5 \text { years after } \\
\text { planting }\end{array}$ & $\begin{array}{l}2 \\
2 \\
2\end{array}$ & & & $\begin{array}{l}1 \\
1\end{array}$ \\
\hline $\begin{array}{l}\text { Carter, Dean, Wang, } \\
\text { \& Newbold (2006) }\end{array}$ & $\begin{array}{l}\text { Gulf Coastal Plain } \\
\text { of USA }\end{array}$ & $\mathrm{Cfa}$ & $\begin{array}{l}\text { Sand/silt/ } \\
\text { clay }\end{array}$ & LTSP & Pinus taeda (-) & $\begin{array}{l}\text { planted (at } \\
\text { age } 1 \text { year) }\end{array}$ & $\begin{array}{l}\text { 3-4 years after } \\
\text { planting }\end{array}$ & 4 & 3 & 3 & 4 \\
\hline $\begin{array}{l}\text { Da silva, de Barros, } \\
\text { da Costa, \& Leite } \\
(2008)\end{array}$ & Brazil & Aw & Clay & field trial & $\begin{array}{c}\text { Eucalyptus grandis } \\
(-)\end{array}$ & l & $\begin{array}{l}1 \text { year after } \\
\text { planting }\end{array}$ & & 3 & & 1 \\
\hline $\begin{array}{l}\text { Heninger et al. } \\
\text { (2002) } \\
\end{array}$ & Western Oregon & $\mathrm{Csb}$ & Loam & $\begin{array}{l}\text { recent } \\
\text { harvest }\end{array}$ & $\begin{array}{l}\text { Pseudotsuga } \\
\text { menziesii }(0)\end{array}$ & $\begin{array}{c}\text { planted (at } \\
\text { age } 2 \text { years) }\end{array}$ & $\begin{array}{l}8 \text { years after } \\
\text { planting }\end{array}$ & 1 & & 1 & 1 \\
\hline Kabzems (2000) & $\begin{array}{c}\text { Dawson Creek } \\
\text { Forest District, } \\
\text { British Columbia }\end{array}$ & Dfc & Silt & LTSP & Picea glauca (0) & l & $\begin{array}{l}3 \text { years after } \\
\text { planting }\end{array}$ & & 1 & 1 & 1 \\
\hline $\begin{array}{l}\text { Kabzems \& } \\
\text { Haeussler (2005) }\end{array}$ & $\begin{array}{l}\text { Dawson Creek } \\
\text { Forest District, }\end{array}$ & Dfc & Silt & LTSP & $\begin{array}{c}\text { Populus tremuloides } \\
(-)\end{array}$ & $\begin{array}{c}\text { natural } \\
\text { regeneration }\end{array}$ & $\begin{array}{l}5 \text { years after } \\
\text { compaction }\end{array}$ & 1 & & & 1 \\
\hline
\end{tabular}


British Columbia

\begin{tabular}{|c|c|c|c|c|c|c|c|c|c|c|c|}
\hline $\begin{array}{l}\text { Kamaluddin, Chang, } \\
\text { Curran, \& Zwiazek } \\
\text { (2005) }\end{array}$ & $\begin{array}{c}\text { Southeastern } \\
\text { British Columbia }\end{array}$ & Dfc & $\begin{array}{l}\text { Sand/ } \\
\text { loam }\end{array}$ & LTSP & $\begin{array}{c}\text { Pinus contorta (-) } \\
\text { Pseudotsuga } \\
\text { menziesii }(0) \\
\end{array}$ & $\begin{array}{l}\text { planted (at } \\
\text { age } 1 \text { year) }\end{array}$ & $\begin{array}{l}1.5 \text { years after } \\
\text { planting }\end{array}$ & $\begin{array}{l}1 \\
1\end{array}$ & $\begin{array}{l}1 \\
1\end{array}$ & & 1 \\
\hline $\begin{array}{l}\text { Kranabetter, } \\
\text { Sanborn, Chapman, } \\
\text { \& Dube }(\mathbf{2 0 0 6})\end{array}$ & British Columbia & Dfc & Silt/clay & LTSP & $\begin{array}{c}\text { Pinus contorta (-) } \\
\text { Picea glauca }(0)\end{array}$ & $\begin{array}{l}\text { planted (at } \\
\text { age } 1 \text { year) }\end{array}$ & $\begin{array}{l}12 \text { years after } \\
\text { planting }\end{array}$ & $\begin{array}{l}1 \\
1\end{array}$ & & & $\overline{1}$ \\
\hline Ludovici (2008) & $\begin{array}{l}\text { Craven county, } \\
\text { Croatan National } \\
\text { Forest, North } \\
\text { Carolina }\end{array}$ & Cfa & loam & LTSP & Pinus taeda (-) & $\begin{array}{l}\text { planted (at } \\
\text { age } 1 \text { year) }\end{array}$ & $\begin{array}{l}10 \text { years after } \\
\text { planting }\end{array}$ & 1 & 1 & & 1 \\
\hline $\begin{array}{l}\text { Murphy, Firth, \& } \\
\text { Skinner (1997) }\end{array}$ & New Zealand & $\mathrm{Cfb}$ & Clay & field trial & Pinus radiata $(0)$ & $\begin{array}{l}\text { planted (at } \\
\text { age } 1 \text { year) }\end{array}$ & $\begin{array}{c}11 \text { years after } \\
\text { planting }\end{array}$ & 2 & 2 & & 1 \\
\hline Perry (1964) & $\begin{array}{c}\text { Durham County, } \\
\text { North Carolina }\end{array}$ & Cfa & l & $\begin{array}{c}\text { old wheel } \\
\text { tracks }\end{array}$ & Pinus taeda (-) & / & at 26 years old & 1 & 1 & & 1 \\
\hline $\begin{array}{l}\text { Ponder, Alley, } \\
\text { Jordan Swartz, \& } \\
\text { Hubbard (1999) } \\
\end{array}$ & $\begin{array}{l}\text { Shannon County, } \\
\text { Carr Creek State } \\
\text { Forest, Missouri }\end{array}$ & Cfa & loam & LTSP & $\begin{array}{c}\text { Quercus rubra }(0) \\
\text { Quercus alba }(0) \\
\text { Pinus echinata }(-) \\
\end{array}$ & $\begin{array}{l}\text { planted (at } \\
\text { age } 1 \text { year) }\end{array}$ & $\begin{array}{l}3 \text { years after } \\
\text { planting }\end{array}$ & $\begin{array}{l}1 \\
1 \\
1 \\
\end{array}$ & $\begin{array}{l}1 \\
1 \\
1 \\
\end{array}$ & $\begin{array}{l}1 \\
1 \\
1 \\
\end{array}$ & 1 \\
\hline $\begin{array}{l}\text { Puetmann, } \\
\text { D'Amato, Arikian, } \\
\text { \& Zasada (2008) } \\
\end{array}$ & Minnesota & Dfb (mainly) & Sand/silt & $\begin{array}{l}\text { recent } \\
\text { harvest }\end{array}$ & $\begin{array}{l}\text { Populus tremuloides } \\
(-) / \\
\text { P. grandidentata (-) } \\
\end{array}$ & $\begin{array}{l}\text { natural } \\
\text { regeneration }\end{array}$ & $\begin{array}{l}\text { 4-11 after } \\
\text { compaction }\end{array}$ & 4 & & & 1 \\
\hline $\begin{array}{l}\text { Simcock, Parfitt, } \\
\text { Skinner, Dando, \& } \\
\text { Graham (2006) }\end{array}$ & $\begin{array}{c}\text { North of } \\
\text { Auckland, New } \\
\text { Zealand }\end{array}$ & $\mathrm{Cfb}$ & Clay & field trial & Pinus radiata $(0)$ & $\begin{array}{l}\text { planted (at } \\
\text { age }<1 \text { year) }\end{array}$ & $\begin{array}{l}3 \text { years after } \\
\text { planting }\end{array}$ & 1 & & 1 & 1 \\
\hline Smith (2003) & $\begin{array}{c}\text { Kwazulu Natal, } \\
\text { Zululand, South } \\
\text { Africa } \\
\end{array}$ & $\mathrm{Cfb}-\mathrm{Cwb}$ & Sand & $\begin{array}{l}\text { old wheel } \\
\text { tracks }\end{array}$ & $\begin{array}{c}\text { Eucalyptus grandis } \\
(-)\end{array}$ & I & at 4-7 years old & & & 5 & 3 \\
\hline Stone \& Elioff (1998) & Minnesota & $\mathrm{Dfb}$ & Sand & LTSP & $\begin{array}{c}\text { Populus tremuloides } \\
(-) / \\
\text { Populus } \\
\text { grandidentata (-) } \\
\end{array}$ & $\begin{array}{c}\text { natural } \\
\text { regeneration }\end{array}$ & $\begin{array}{l}5 \text { years after } \\
\text { compaction }\end{array}$ & 1 & 1 & & 1 \\
\hline $\begin{array}{l}\text { Stone \& Kabzems } \\
(\mathbf{2 0 0 2 )}\end{array}$ & $\begin{array}{c}\text { Minnesota, British } \\
\text { Columbia }\end{array}$ & Dfb-Dfc & Silt & LTSP & $\begin{array}{c}\text { Populus tremuloides } \\
(-) / \\
\text { Populus } \\
\text { grandidentata (-) } \\
\end{array}$ & $\begin{array}{l}\text { natural } \\
\text { regeneration }\end{array}$ & $\begin{array}{l}5 \text { years after } \\
\text { compaction }\end{array}$ & 4 & & & 2 \\
\hline $\begin{array}{l}\text { Tan, Curran, Chang, } \\
\text { \& Maynard (2009) }\end{array}$ & British Columbia & Dfc & $\begin{array}{l}\text { Loam- } \\
\text { silt/sand/ } \\
\text { clay }\end{array}$ & LTSP & $\begin{array}{c}\text { Pinus contorta (-) } \\
\text { Pseudotsuga } \\
\text { menziesii }(0)\end{array}$ & $\begin{array}{l}\text { planted (at } \\
\text { age } 1 \text { year) }\end{array}$ & $\begin{array}{l}3 \text { years after } \\
\text { planting }\end{array}$ & & & $\begin{array}{c}3 \\
3(1 \\
\text { outlier })\end{array}$ & 3 \\
\hline
\end{tabular}


